Article

\title{
Younger Infants in the Elementary School: Discursively Constructing the Under-Fives in Institutional Spaces and Practices
}

\author{
Yinka Olusoga \\ Carnegie School of Education, Leeds Beckett University, Headingley Campus, Leeds LS6 3QQ, UK; \\ Y.Olusoga@leedsbeckett.ac.uk
}

Received: 6 May 2019; Accepted: 5 July 2019; Published: 9 July 2019

\begin{abstract}
Expansion of state-regulation of education and care for under-fives in England has seen increasing numbers of under-fives attending primary school early years provision in the 21st century's opening decades. However, this is not entirely novel as under-fives attending elementary school feature in numerous 19th and 20th century reports. This article examines how under-fives have been discursively constructed in three reports between 1861 and 1933. Changing conceptualizations of under-fives are reflected in these documents. Shifting discourses of schooling, child development and curriculum are deployed, adapted or silenced to frame and judge the personal, social and moral conduct of the young child and parent. This normalizing discursive gaze positions the spaces and practices of schooling as necessary interventions inculcating specific governmentally designated desirable aspects of the child. Under-fives are enmeshed in an advancing process of educational colonization that removes them from the home, coming to dominate their time and experiences as young children. Current trends towards earlier school starting ages, longer daily hours, and the forensic use of data to chart progress towards expected goals is extension of this pattern. Attending to the genealogy of the discursive rationalization of this process helps us to critique how similar contemporary policy arguments are made.
\end{abstract}

Keywords: under-fives in elementary schools; purposes of nursery schooling; schooling for parental responsibility; maternal duties; school readiness

\section{Introduction}

For more than 150 years, the early care and education of young children in England has been a focus of official policy discussion. From the Report of the Newcastle Commission in 1861 (Education Commission 1861a), to ongoing debates in the 2010s (Gibb et al. 2010; Office for Standards in Education Ofsted), the status and treatment of children under five in state-funded school provision has been a focus for educational, social political attention. The desirability of including or excluding under-fives from state-funded school provision has been shaped at different points in time by a range of competing, overlapping and contradictory discourses (Palmer 2011; Read 2015). These discourses are informed by ideas about the role of the parent (especially of the mother), of the role the state and its institutions, and about the nature of children. What is notable in these discourses is the intersection between social class and gender and a tendency for the needs of the child to be constructed in terms of the needs of the system, of society and of the economy. This article will examine three historical reports that address the issue of under-fives in what was originally termed elementary education. They are the Report of the Newcastle Commission (Education Commission 1861a), the Report of the Consultative Committee upon the School Attendance of Children Below the Age of Five (Board of Education 1908), and the Hadow Report on Infant and Nursery Schools (Board of Education 1933). Finally, this article will reflect 
on changes and continuities in these constructions across these documents and into contemporary (at the time of writing) policy debates.

\section{Method}

The theoretical frame for engagement with these texts draws on Foucault's work on discourse and on genealogy (Foucault 1970, 1972). It employs an understanding of discourse as productive. Discourse does not merely describe what already exists; it produces habitual linguistic practices that name, construct and act on people and groups as objects of knowledge to be classified and sorted. Furthermore, Foucault's concept of genealogy identifies how power and knowledge are fused. His concept of Power/Knowledge allows analysis of the social and material consequences of discourse. These consequences can be traced in the debates and reports on the care and education of young children and in the accompanying development of dividing, disciplinary practices that classify and sort children and families. Application of Foucault's ideas helps this study to uncover the growth and development of nurseries and schools as institutions of surveillance that bring increasing numbers of children and families and under their normalizing gaze (Foucault 1977). The analysis of the historical texts under scrutiny focuses on how under-fives, their parents and homes, and institutions for their care and education outside the home are discursively constructed at these earlier points in time in the 19th and 20th centuries. Informed by the discourse-historical approach to critical discourse analysis (Reisigl and Wodak 2016), this discursive construction is traced by considering the ways language is used to name and characterize children, parents, homes and provision in the historical reports under examination. The focus texts have been read and re-read iteratively to facilitate an analysis of the nature of the arguments employed in this naming and characterizing, noting on which grounds they are predicated. These multiple readings also take note of whose perspectives are taken, who is written about and whose views are represented, whose ignored or undermined, and how language is used to intensify or mitigate the arguments presented in the texts.

\section{Infants Schools versus Dames' Schools: Discursively Constructing Schools for Children in Infancy in 1861}

\subsection{The Royal Commission on Popular Education, 1861}

Nine years before state education became compulsory for children aged between five and 10 in England and Wales, the Newcastle Commission was asked to enquire into the state of popular education and to consider whether it needed to be extended. State involvement and funding of education for the working classes was a highly contentious issue, with some arguing for the development of a proper national system of state-supported education, and others deeply opposed to the idea (Aldrich 2006). To discharge this task, the Commission, via the work of its Assistant Commissioners, conducted a survey of nine specimen regions of the country. This involved visiting schools, talking with school managers and gathering evidence from those who dealt with the working classes in a range of fields including employment, policing, and religion. In addition, the Commissioners sent out a circular of questions, selected and called expert witnesses, collated and surveyed decades of official statistics and reports on education and related issues and commissioned reports on the situation in other countries. The result of their work was published in 1861 in a six-volume report. Volume I of the Report examined the range of types of schooling available to the mass of the independent poor (by which it meant those able to earn a living rather than being reliant on indoor or outdoor poor relief), as well as that provided for pauper children and children they classed as 'vagrants and criminals' (Education Commission 1861a, p. 386).

For 'children above infancy' who came from families classed as the independent poor, the Report discussed day (elementary) schools, evening schools and Sunday schools (Education Commission 1861a, p. 28). For younger children, it discussed the infant school, a category it sub-divided into 'the private or dames' schools' and 'the public infant schools' (Education Commission 1861a). So-called 
Dame Schools had existed for centuries and were a popular option for families of all respectable classes, but many issues had been raised about these, including variable quality and the fact that some operated purely as a minding service, were often managed by very elderly women, and due to lack of regulation, could put children in danger due to over-crowding. Infant schools, on the other hand, tended to be departments of existing day schools, regulated and inspected by the state. It was in these discussions that the working-class parent and home were discursively constructed, and the working-class child characterized as in need of early intervention in state-approved institutions for its care and instruction.

\subsection{The Working-Class Parent and the Need for Schools for Children in Infancy}

The Report stated that infant schools provided:

the sort of instruction which in the wealthier classes of society is conveyed almost imperceptibly by constant intercourse with educated persons. (Education Commission 1861a, p. 28)

By contrast, the Report's view of the interactions between working-class parents and their children was one that stressed their presumed ignorance, lack of resources and the consuming nature of their economic and domestic labor:

In the family of a mechanic or day labourer, to say nothing of the ignorance of the parents, the father is usually at work from six in the morning till six at night. The mother has to perform personally all household operations. Stationery and books are too valuable to be made into toys. The house is not furnished with objects which awaken intelligence, nor has anyone leisure to form the manners and temper of the child. (Education Commission 1861a, p. 28)

In line with practices in other comparable counties such as Germany, France and America, in the 1860s the nominal starting age for most day school provision in England and Wales was six or seven. However, the Report found that children attended infant schools 'from the very earliest age at which they are able to walk alone and to speak' (Education Commission 1861a, p. 28). The Report positioned the infant school as the solution to practical and social problems associated with the containment of the very young. Infant schools were described as:

the only means of keeping the children of such families out of the streets in towns, or out of the roads and fields in the country. (Education Commission 1861a, p. 28)

Thus, very young children were characterized as both in potential danger and as a potential threat to the functioning of public spaces. The Report considered the educational worth of the infant school lay not in the amount of knowledge that very young children gained (acknowledged as 'apparently small in amount' but 'of high value'), but in its ability to instill 'habits of docility and submission to discipline' (Education Commission 1861a, p. 28).

\subsection{The Dames' Schools versus the Infant Schools}

Having established this role for infant schools, the Report compared the dames' schools and the government-inspected public infant schools. At the heart of the discussion was an ideological tension between the concepts of care and of education, and between provision for the young child that mimicked the atmosphere of the home and institutional provision that reflected the roles and practices of schooling. The descriptions of the dames' schools contained some of the most striking and emotive language in the entire Report. The uninspected, domestic and feminine aspects of the provision were construed as highly problematic. Dames' schools were dismissed as being 'little more than nurseries run by women generally advanced in life' (Education Commission 1861a, p. 29) who looked after children from their local communities. The Report stated:

their school is usually their kitchen, sitting and bed-room and the scene of all their domestic occupations. (Education Commission 1861a, p. 29) 
It described how dames' schools were 'apt to be close, crowded, and dirty' with an atmosphere so 'oppressive' as to make a visitor feel sick (Education Commission 1861a, p. 29). Against this was contrasted the public infant school, characterized and positioned as a far preferable, clinical and institutional space.

\subsection{The Purpose and Outcomes of Schooling for the Working-Class Infant}

The distinctive look and feel of the public infant school were emphasized in the Report. Public infant schools, it stated presented a 'different appearance' as a result of the 'attention ... bestowed upon their organization'. Further distinction was made with the claim that, unlike the dames' schools they:

not only aim at, but in fact accomplish, a great deal more than the simple objective of keeping children out of mischief. (Education Commission 1861a, pp. 29-30)

The Report outlined the educational approach of the public infant school in some detail and discursively characterized the young child in terms of its ability to engage in different types of educational activity. Divided into two classes, the youngest children (i.e., the under-fives) in such schools engaged in activities to promote talking, develop their physical skills and to learn 'their letters' (Education Commission 1861a, p. 30). The older infant children in the higher division were told stories, including bible stories, learned basic arithmetic using suitable equipment and were 'exercised in plaiting, tying knots, sewing, and other occupations which employ their hands' (Education Commission 1861a, p. 30). This instruction was deemed to demand a teacher with 'tact, patience, and ingenuity' with a 'special taste for the occupation' (Education Commission 1861a, p. 30).

An emphasis on the need for the social and moral training of children, in ways that they would come to embody, was reflected in the statement that:

Churches are good, and ordinary schools are good, but they only modify bad habits already contracted. Infant schools prevent bad habits been formed. (Education Commission 1861a, p. 31)

The very young children of the poor were thus discursively framed as in need of a program of moral inculcation that would instill in them habits of thought and action and reduce time spent in the contaminating influence of home. The outcome of such instruction was physically and socially evident in the children, who received in the public infant schools:

training in obedience, attention, observation, and facility of comprehension, which distinguishes them at a glance from children who have not had the advantage of an infant school training. (Education Commission 1861a, p. 31)

Finally, the Newcastle Commission Report drew on the testimony of Mr. Shields, a London headmaster called before the Commissioners as an expert witness. He argued that an extension of government support to develop public infant school provision would facilitate careful preparation of young children. In his evidence he stated that he would admit children into the infant class of his day school 'as soon as they could be brought' and keep them 'as a rule till they are seven years of age' (Education Commission 1861b, p. 531). This he argued could essentially speed up the process of educating them in the day schools from age seven so that they could 'thoroughly well all the absolute essentials of education by 11 years of age' (Education Commission 1861a, p. 31).

Although the Report of the Newcastle Commission did not immediately lead to the establishment of a national system of education, it did prove to be highly influential in shaping the debates in parliament that resulted in the 1870 Elementary Education (Foster) Act. The decision in 1870 to set the school starting age at five drew on the same economic arguments and the same logic of starting educational instruction early (House of Commons Debate, 1870). The dim official view of the dames' schools and the preference for institutional rather than homelike spaces for very young children meant that by the turn of the 20th century local school boards allowed children under five to attend public elementary schools, often in buildings and with equipment poorly suited to their needs. 


\section{Public Elementary Schools versus Nursery Schools: Discursively Constructing Provision for Under-Fives in 1908}

In April 1907, the Consultative Committee had been charged by the Board of Education to provide advice:

in regard to the desirability, or otherwise, both on educational and other grounds, of discouraging the attendance at school of children under the age of (say) five years. (Board of Education 1908, p. 11)

The eventual report, published in 1908, largely took up the themes established in an earlier report on the same subject by the women inspectors in 1905. That report had argued that where children came from 'good homes' run by 'careful mothers', attendance at elementary school under the age of five was both unnecessary and unnatural (Board of Education 1905b, p. ii). The subsequent Elementary Code for 1905 issued by the Board of Education reflected this and included an amendment to Article 53 which gave Local Education Authorities (LEAs) the right to refuse admission to school of children under five (Board of Education 1905a, p. 21). In cases, however, of children with working mothers or from what they termed 'imperfect homes' they were, in the words of Katherine Bathurst, one of the most critical of the women inspectors, being 'sacrificed ... to the selfishness of their overworked mothers' (Board of Education 1905b, p. 75). In these circumstances the Report recommended that attendance at school was preferable to staying at home. However, they warned against formal approaches to teaching very young children and of the impact of unsuitable furniture and resources on their physical and intellectual development. In the preface to the Report, the Chief Inspector, Cyril Jackson argued that the women inspectors had agreed unanimously that there was 'no intellectual advantage from school instruction' (Board of Education 1905b, p. i), a claim that Read (2015) argues did not capture the nuance of their argument about the failings of unsuitable provision but also of the potential of appropriate pedagogic approaches. The preface continued, stating:

It would seem that a new form of school is necessary for poor children. The better parents should be discouraged from sending the children before five, while the poorer who must do so, should send them to nursery schools rather than the schools of instruction. (Board of Education 1905b, p. ii)

Attendance at elementary schools of under-fives was a still a pressing question two years later when the Board of Education commissioned the second report on the issue, this time provided by the new Consultative Committee on Education. Despite LEA powers granted in 1905 to refuse admission to children under the age of five 'at least a third' of children between the ages of three and five were registered at public elementary schools (Board of Education 1908, pp. 11-12). Furthermore, little had been provided in the way of nursery provision in light of the 1905 recommendation. The debate on the issue of very young children was positioned in the 1908 Report as partly a medical issue. The first set of witnesses listed in the report were new medical officers, and the report discussed concerns around the stunting the physical and intellectual development of young children and their potential exposure to disease in large, overcrowded classrooms and schools. However, in the bulk of the Report, the school attendance of under-fives was framed as a social issue. Drawing on discourses of social class, gender and eugenics (Read 2015), the issue was argued as arising primarily from a failure of working-class families to provide decent homes and of working-class mothers in particular to provide adequate parenting.

\section{1. 'Imperfect Homes': Maternal Duty and Poverty}

The 1908 Report stressed, as the 1905 Report had, that the ideal place for young children was the home and that alternative provision was only necessary in cases when the home conditions fell below a certain standard. Discussion of 'imperfect' homes focused on the need for each mother to do 'her duty by her children' (Board of Education 1908, p. 16). Proper maternal duty towards working-class 
children, according to the Report, involved a mother knowing 'how to care for them properly and to make the best use of her narrow means' (Board of Education 1908, p. 16). Additionally, it meant avoiding employment that would 'keep her out of the home', as well as keeping the home 'clean, well-lighted, well-ventilated, and not over-cramped' with a 'safe space' for the child to play outdoors (Board of Education 1908, p. 16). The 'natural relationship between mother and child' and 'the other influences of good home life', the report argued, represented 'a moral and educational power' (Board of Education 1908, p. 16). Furthermore, this power was one of:

high national importance to preserve and to strengthen, ... which educational policy should be careful not to impair. (Board of Education 1908, p. 16)

Thus, the need for women to perform their maternal duty was framed as a form of good citizenship, and a moral duty to the nation, not just to the child. This maternalistic discourse (Read 2015) was informed by the prevalent eugenic discourse (Heathorn 2000; Hendrick 1997), in which children were viewed as genetic stock to be tended by mothers and on whom the health, vigour and progress of the nation depended.

State supported care or educational provision for all under-fives was positioned in the Report as a potential threat to the natural role of the mother and development of the child and to the natural place of women in the home rather than in the workplace. The Report, however, acknowledged that as well as there being some parents 'not sufficiently alive to the well-being of their children' to provide these ideal home conditions, there were also 'many mothers ... anxious to do their whole duty towards their children' but who were 'unable to train them [the children] properly owing to various circumstances' (Board of Education 1908, pp. 16-17). Such circumstances included lacking 'the necessary means or accommodation' or being 'compelled to leave home during the day and go to work' (Board of Education 1908, p. 17). Poverty and economic disadvantage were thus alluded to, however the Report firmly stated that it was outside 'the province of the Committee to suggest how these difficulties may be overcome' (Board of Education 1908, p. 17). The Report argued that improved 'educational opportunities' would contribute to a:

steady decrease in the number of those homes in which little children fail to receive the inestimable advantage of right parental care. (Board of Education 1908, p. 19)

Thus, instead of acknowledging societal and structural forces impacting on the ability of families in poverty to provide for their children and to make choices about their care, the focus of the Report remained one that individualized families in poverty and blamed mothers for the existence of these imperfect homes. It positioned education as the means for improving behaviour of the very poor, both as very young children and eventually as parents, without acknowledging any need to address the structural causes of poverty.

\section{2. 'Minders', Crèches and Nursery Schools: Care and/or Education for Under-Fives}

Having side-stepped discussion of the wider causes of imperfect homes, the Report considered the alternatives available to mothers (not parents) seeking care and/or education for their children under five. Leaving children unattended inside or outside the home was, obviously, dismissed as an option. Leaving children with a neighbor came under the same restrictions as staying with the mother, as neighboring homes were likely to be imperfect for similar reasons. Echoing the findings of the Newcastle Commission of 1861, the 1908 Report took a vociferously dim view of unofficial and non-institutional provision. The Report stated that the 'professional 'minder' is almost always unsatisfactory' (Board of Education 1908, p. 18). Lamenting that the lack of centralized inspection and control over such provision, the Report described minders as 'ignorant women' and their homes as 'dirty and insanitary', and stated:

It is a well-proved fact that it is a common practice in such places for children to be drugged in order to keep them quiet. (Board of Education 1908, p. 18) 
Against this domestic, community-based unofficial provision the Report contrasted institutionbased provision for under-fives. The Report named the crèche and the Infant School as institutions catering for under-fives, the essential difference between the two being the educational focus of the Infant School, which was absent from crèche provision. Having identified the existence of crèches, supported via voluntary charities and the award of local government grants in some areas, they, and the children who attended them, were not the main focus of the Report. Instead, attention was paid to discussing the pros and cons of the Infant School. The Committee was keen to stress that infant schools differed widely and that concerns about the general attendance of under-fives in public elementary schools could be allayed by the development of the right sort of infant school provision. Echoing the earlier concerns of the women inspectors, the Report stated that putting young children 'under formal instruction and discipline' (Board of Education 1908, p. 19) as was the case in the infant departments of some Public Elementary Schools, was not good practice. At the other end of the spectrum, however, it identified nursery and infant school provision that was designed to acknowledge and address the specific needs of the very young. Here, the Report stated:

the special needs of small children are met by the provision of special rooms, special curriculum and special teaching. (Board of Education 1908, p. 19)

Expanding on this discussion the Report set out its description of the 'characteristics of the ideal institution for younger infants' (Board of Education 1908, p. 20). That institution was the nursery school and the Report very much championed its cause. In so doing, it also discursively constructed the particular child for whom such provision was in the Committee's view necessary; the type of teacher suited to the task and the projected outcomes of the child's nursery school experience.

\subsection{Describing the Younger Infant: Characteristics and Needs}

The 1908 Report devoted attention to considering the particular characteristics of younger infants as a means of justifying a need for distinct provision designed to meet their needs. They were described in the Report as being 'even more dependent on light, air and sunshine than older children' (Board of Education 1908, p. 20). They thus required easy access to a partially covered playground that could accommodate them in all weathers in which, ideally, they should 'spend half the day' (Board of Education 1908, p. 20). Indoors they required classrooms with 'much more floor space' due to their 'natural instinct for movement' (Board of Education 1908, pp. 20-21). Furniture needed to be flexible and moveable to accommodate change and children should be provided with space to sleep, preferably 'in the open-air under proper conditions' (Board of Education 1908, p. 22). Formal lessons in the three Rs 'should be rigidly excluded' and 'no inspection or examination of results in such subjects allowed' (Board of Education 1908, p. 21). Instead, children should engage in a range of hands-on activities, including engaging with Froebelian 'Kindergarten gifts' and in story-telling, drama and other activities to develop their talking and listening (Board of Education 1908, p. 21). In addition:

Cleanly habits and ready obedience should be secured by a discipline which is kindly, but not unduly repressive. (Board of Education 1908, p. 21)

\subsection{Advantages of Nursery School: Moral, Physical and Mental}

The justification for the nursery school was further enhanced in the Report by a section examining the advantages younger children would gain from attending such nursery schools. The advantages were classified as being moral, physical and mental. The primacy of moral advantages in the list reflected the argument that such provision should only be aimed at children from the economic and social margins of the working-classes and was predicated on a Malthusian discourse that linked immorality and poverty (Cremaschi 2014). According to this discourse, these were families whose poverty and imperfect homes were signs of an intergenerational moral contamination that schooling must seek to address. The moral advantages listed focused on the role of early schooling in physically containing and morally treating under-fives from such families, allowing them to learn 'important 
lessons which more fortunately placed children learn at that age in their homes' (Board of Education 1908 , p. 24). Nursery schools could keep such children 'away from the dangers and temptations of the streets', instead offering 'cleaner and more wholesome surroundings' than their homes could provide (Board of Education 1908, p. 24). Furthermore, there was a surveillance element as such provision kept the children 'under the eye of a teacher whose influence should be all for the good', where they could be taught:

to be truthful, kindly, and honest; to be cleanly and tidy in their persons; to be disciplined and obedient in their habits. (Board of Education 1908, p. 24)

The physical advantages outlined in the Report also had a moral aspect and widened surveillance to cover the parents and the mother in particular. School, and the structure that it imposed on family life in relation to time-keeping, meals, clothing and cleanliness, the Report stated, tended 'to improve the physical development of the child' (Board of Education 1908, p. 25). Close observation of this physical development also increased opportunities for teachers and medical staff to detect in children 'diseases and weaknesses, such as defects of sight and hearing' (Board of Education 1908, p. 25). The alleged mental advantages of the infant school were less clearly stated. The Report acknowledged the concerns of some that early attendance at school could lead to the minds of the child becoming 'dulled and injured by being overworked' (Board of Education 1908, p. 25). However, it argued that this would be avoided in provision that followed the 'general nature and function' (Board of Education 1908, p. 25) of the ideal nursery school that had been outlined by the Committee.

\subsection{Constructing the Nursery School as a Site of Surveillance}

From this discussion of the advantages of nursery schools for under-fives from imperfect homes, a key theme is one of surveillance, both the child and the parent, and especially of the mother. Attendance of a specific class of working-class child in the nursery school could facilitate their early physical surveillance under the normalizing gaze (Foucault 1977) of schooling. This could operate alongside a social surveillance of their behavior and of their capacity for obedience. Nursery schools, as proposed by the Committee, could monitor and mold the child's behavior, but also the quality of parenting. Judgements made against criteria of focused on the child's physical appearance were in effect also proxy measurements of the performance of respectability by the mother in submitting to the specific requirements of school attendance, punctuality, dress and cleanliness. The Report addressed the concern that some would perceive the provision of nursery schools are relieving some of the burden of parental responsibility 'to the moral detriment' of the child and parent (Board of Education 1908, p. 26). Instead, the Committee argued, this provision, targeted at specific homes and families, would actually have the opposite effect:

in the case of the children under consideration their attendance at school might be a useful means of bringing home to their mothers a livelier sense of their parental duties. (Board of Education 1908, p. 26)

Publicly-funded nursery schools, the Committee argued, should be provided under the discretion of the LEA, for under-fives coming from imperfect homes. Organizationally they should be attached to Public Elementary Schools and ideally be open for the same hours to facilitate children being taken to school by or with older siblings (Board of Education 1908, p. 22). As the Nursery School would, unlike the professional minder or non-educational crèche, offer 'something more than mere nursing' it would come 'under the supervision' of the LEA and would employ 'special methods' and offer the children 'training' that was 'in the proper sense, educational' (Board of Education 1908, p. 53). As well as benefitting from this educational training, the transfer of children at the end of their time in nursery to the infant department would be facilitated by them having 'already been grouped in classes' which would make it 'easier to arrange for their preparation for the classes in the upper school' (Board of Education 1908, p. 53). Thus, despite the Report's eschewing of formal teaching practices for the 
under-fives, there was a role for the nursery in institutionalizing and preparing the children for the demands and practices of the next phase of their education.

As was the case with the 1861 Report of the Newcastle Commission, the impact of the 1908 Report of the Consultative Committee was not immediate. However, Article 19 of the 1918 Education Act did finally give LEAs the power to provide publicly-funded nursery schools or nursery classes for three to five-year-olds. This was the socially targeted provision the 1908 Report had argued for, aimed children for whom attendance was deemed 'necessary or desirable for their heathy physical and mental development' and the provision was to attend to the children's 'health, nourishment, and physical welfare' (Great Britain 1918, 8 \& 9 Geo. 5). The resultant provision also had to be open to inspection by the LEA. Take up of the powers of the Act, however, was limited and geographically uneven.

\section{Under-Fives in Nursery Schools and Nursery Classes in 1933}

\subsection{The 1933 Report on Infant and Nursery Schools}

The 1933 Report of the Consultative Committee on Infant and Nursery Schools was the last in a trio of reports focusing on the various stages of the education system (secondary, primary, and finally infant and nursery). Twenty-five years on from the 1908 Report discussed above, the trend was for infant provision to be in schools or departments separate from junior provision. Nursery schools offered provision from age two, targeted at children living in slum conditions, at the discretion of the local authority, nursery classes within infant school took children from the age of three. Only 30 separate nursery schools had been established by LEAs, with a further 25 run by voluntary bodies (Board of Education 1933, p. xv). Therefore, the majority of children receiving state funded nursery provision did so in nursery classes in primary schools, attending the nursery classes between the ages of three and five and the infant classes from five to age seven (Board of Education 1933).

From the beginning the tone and language of the Report strikingly reflected educational, psychological and medical discourses of child development that were international in scope. Key educational theorists and researchers such as Dewey, Montessori and Isaacs were named, and a focus on the supervision and measurement of children's growth and development informed the discussion. Since the turn of the 20th century, the proportion of children under-five attending elementary schools had dropped from a high of 43\% in 1900 to 13\% in 1930 (Board of Education 1933, p. xv). However, an English tradition of nursery provision and practice had developed, and the Report cited Rachel and Margaret McMillan's outdoor nursery in Deptford (Board of Education 1933, p. 101) and quoted from Grace Owen's 1930 pamphlet 'Education and Nursery Schools' (Board of Education 1933, p. 102). This tradition placed an emphasis on outdoor play, on regular medical supervision focused on physical development and health, and on social training (Read 2015). In line with the exhortations of the women inspectors in 1905, the Report argued that formal approaches to instruction were not part of this nursery tradition. All of this was reflected in the Report's description of the ideal nursery school which:

should not be 'institutional' in character, but as far as possible of a light and open 'garden pavillion' type. It will consist of a number of class (or play) rooms, rooms for the staff, a room for observation and medical treatment, a kitchen, lavatories and offices. The ideal school is the light single-storey building of the open-air type set in a garden playground; the playground is centrally placed between the classrooms. (Board of Education 1933, p. 169)

\subsection{The Aims, Functions and Outcomes of Nursery Provision}

In the Report, the Committee reviewed the aims and function of nursery schooling under three headings; namely, the 'medical or hygienic aspect', the 'educational aspect' and the 'social aspect' (Board of Education 1933, p.103). The section of the Report outlining the educational aspect of the nursery school was very brief and emphasized the role of play, rather than formal instruction in children's learning. The section that addressed the medical aspect outlined how nursery provision 
had become part of the state machinery for medical surveillance of young children that had been recommended in the 1908 Report. Nursery school practice included:

inspections by the school doctor not less than once a term and sometimes once a month; frequent visits by the school nurse; the systematic measuring and weighing of the children; the exercise of great care in the detection and isolation of cases of infectious illness; and the keeping of a medical record for each child. (Board of Education 1933, p. 104)

The Report thus identified and characterized the under-fives from poor homes who attended nursery schools as children whose physical health was under particular threat in their inadequate homes and communities. Nursery school therefore was positioned as providing the constant medical surveillance and necessary space and facilities for their physical development and training.

The social aspect of nursery schools addressed the personal and social conduct of the child and, potentially, of the parents, characterizing both as in need of intervention. The impact of a poor home environment on children's personal and social development was discussed in the Report in psychological rather than purely moral terms, reflecting changing discourses of education in which both nature and nurture were implicated. The Report stated that 'most psychologists' contended that the mental development of very young children was 'to a large extent determined by specific tendencies which are inherited' (Board of Education 1933, p. 75). In addition, however, the child's early environment played a part and the Committee argued:

Most causes of moral abnormality and perversion, of nervous disorder and faulty habit-formation, have their roots in these initial years of life. (Board of Education 1933, p. 118)

Attendance at nursery school afforded a compensatory training of 'the child in right personal and social behaviour', via the influence of 'companions of his [sic] own age' and 'sympathetic adults who are able to train him in good habits' (Board of Education 1933, p. 105). Thus, the nursery child could be prepared to become 'a useful member of the community' (Board of Education 1933, p. 105).

\subsection{Nursery Provision and the Development of Parental Responsibility}

A theme of the 1908 Report had been parental concern that nursery provision could further undermine the responsibility of parents who were judged as providing imperfect homes for their children. In 1933, however, the Committee were clear in their view that nursery school was able to increase feelings and capacities for parental responsibilities in the families targeted by the provision. The Report argued that nursery schools were able to exert 'through the child an influence for good on the standards and ideals of the home' (Board of Education 1933, p. 105). This influence was fostered by the establishment by nursery schools of 'mothers' clubs or guilds' (Board of Education 1933, p. 105). The Report stated:

Directly or indirectly the mothers gain through these organisations fuller knowledge of their children's needs and possibilities. (Board of Education 1933, p. 105)

Open days, where parents were invited as 'interested spectators of the daily round of school activities' (Board of Education 1933, p. 105), were also cited as means of extending influence of the nursery to the home and of enlisting parents to contribute to the provision in specific, gendered ways:

The gratitude of the parents is displayed in many ways, for instance mothers help in washing school linen and overalls, and fathers construct toys, and attend to the garden. The sense of parental responsibility is increased, rather than diminished by the attendance of young children at the nursery school. (Board of Education 1933, p. 105)

This discourse on poor working-class parents reflects an intersection of social class and gender. The parents were to be instructed and trained, their poverty taken as proof of their lack of knowledge and inability to be the force for good their children required. They were required to work in partnership 
with nursery and its staff, but this was a partnership where they watched, learned and followed the instructions given to them. Proof of the impact of the positive influence exerted on them by the nursery was in their practical, gendered performance of gratitude via their gendered labour.

\subsection{The Limitations of Nursery Provision}

The 1933 Report reiterated the argument presented in 1908 regarding the social need for targeted nursery provision. Nursery schools and classes were, it argued:

a remedial agency affording partial compensation for unfavourable home environment, and should therefore be provided first in districts where home conditions are bad. (Board of Education 1933, p. 112)

The 1908 Report had maintained a silence on the wider social, economic and political context, that effectively served to individualize and blame parents as the sole cause of their poverty and imperfect homes. The 1933 Report still positioned the correct performance of motherhood as the essential factor in the child's life. Indeed, it argued that 'systematic efforts' in the primary school curriculum 'to give the older girls some instruction in house craft and infant care' (Board of Education 1933, p. 113) would in time decrease the number of children living in inadequate homes. The Committee, however, also argued that the 'problem of the physical and mental welfare' of under-fives was 'essentially sociological' (Board of Education 1933, p. 186) and that action outside of the sphere of early childhood education and care was necessary to make any serious attempt to solve it. Urban poverty in particular created home conditions that the Committee felt were 'the very opposite' of the child's 'natural biological environment' (Board of Education 1933, p. 119). The Report stated that:

Bad housing, bad home environment, and economic hardship may be palliated and even ameliorated to nursery schools and classes; but the remedy calls for other action by the state and local authorities. The provision of schools, whatever be the scale on which is made, so long as these conditions survive, leaves untouched the problem of the child's early environment. (Board of Education 1933, p. 119)

The nursery school, therefore, was positioned by the Committee as 'a desirable adjunct to the national system of education' where local 'economic conditions' created an 'unsuitable environment' resulting in children under-five who:

require careful attention to their physical welfare, and need to spend longer hours at school and to be provided with meals. (Board of Education 1933, pp. 187-88)

Although nursery provision could address the problems arising from the child's early environment, it and wider schooling in general could not, in the opinion of the Committee, solve and eradicate it; that would require a concerted, coordinated economic and social change.

\section{Under-Fives in School in the 21st Century}

In the period examined above, from 1861 to 1933, care and education provision for under-fives in England was hugely variable in scale and quality across England. In the absence of a focused state system of nursery provision, there was an expectation that private and voluntary institutions would make up much of the sector and that ideally families, and in particular mothers, would provide care and education in the home (Penn 2014). This largely continued to be the case until the end of the 20th century. However, in the late 1990s and early 2000s, the then New Labour government began to challenge aspects of this status quo. The period saw a vast increase in funding, the introduction of Children's Centers, but also a concomitant higher level of scrutiny for public and private early years provision. Increased early years provision was, to begin with, designed to offer universal services. However, the Sure Start policy was linked to an economic imperative focused on reducing 'welfare dependency' (Read 2015, p. 52). Getting parents, particularly lone parents the majority of whom were 
lone mothers, into the workplace and contributing to the economy required additional early years provision (Moss 2014; McDowall Clark and Baylis 2012). As well as the additional public provision, the New Labour government was committed to a continuation of a mixed public/private economy, covering private nurseries and childminders (as were the subsequent Coalition and Conservative governments), despite issues with the levels of poor quality in private childcare provision (Faulkner and Coates 2013). The non-statutory Curriculum Guidance for the Foundation Stage (CGFS) (Qualifications and Curriculum Authority QCA) was issued to schools with nursery and reception classes. This was followed by the publication of the non-statutory Birth to Three Matters guidance (Department for Education and Skills DfES) issued settings and individuals working with young children aged three and under. The Childcare Act 2006 (Great Britain 1918, c. 21) brought birth to five together, nominally removing the divide between care and education (McDowall Clark and Baylis 2012). By 2008 the Early Years Foundation Stage (EYFS) documentation was introduced with its statutory framework document (Department for Children, Schools and Families DCSF) and non-statutory practice guidance (Department for Children, Schools and Families DCSF). Within the space of a decade, the approach of primary schools to the education of under-fives had undergone significant changes.

\subsection{The Report of the Independent Review on Poverty and Life Chances}

With the 2008 global economic crash and, in the UK, the subsequent economic austerity of the Coalition government from 2010, funding for early years provision was drastically scaled back and increasingly targeted at a smaller sub-group of the poor (Lloyd 2015), who were heavily problematized in the policy discourse. On coming to power in 2010 the Coalition government of Conservatives and Liberal Democrats commissioned the 'Independent Review on Poverty and Life Chances', chaired by Labour Member of Parliament, Frank Field. It was charged by the then Prime Minister, David Cameron:

to consider how home circumstances impact on children's life chances, and in particular how this home background determines a child's readiness for school. (Cabinet Office 2010, p. 12)

The final report, 'The Foundation Years: preventing poor children becoming poor adults', was published in December 2010 (Cabinet Office 2010). It set out an argument for funding of support for developing parenting skills and early education of children under five from economically disadvantaged backgrounds as the means of tackling child and cross-generational poverty and delivering social mobility. The introduction to the Report stated:

It is family background, parental education, good parenting and the opportunities for learning and development in those crucial years that together matter more to children than money. (Cabinet Office 2010, p. 5)

The Report continued:

while income is still important, it is not the exclusive or necessarily the dominant cause of poverty being handed on from one generation to another. The fact that non-income factors, such as the home learning environment and quality of childcare, are so important in deciding the fate of children has led us to construct a set of Life Chances Indicators. (Cabinet Office 2010, p. 12)

Thus, poverty was framed in the Report as a familial issue rather than a structural and economic issue. Therefore, against the backdrop of the Government's program of 'Austerity', which saw vast cuts at local and national level to a range of public services, the role of the state in relation to child poverty could be a narrow, education and care one, rather than an economic, employment, wages and benefits-driven one. The Report justified an individualized and localized focus on supporting the development of parental skills and funding for out-of-the-home education and care provision aimed at 'improving the abilities of our poorest children during the period when it is most effective to do so' (Cabinet Office 2010, p. 6). The Report argued: 
Children need nurturing far longer than any other species and the quality of this nurturing has a major impact on how well children develop and then fulfil their potential. This task is not primarily one that belongs to the state. We imperil the country's future if we forget that it is the aspirations and actions of parents which are critical to how well their children prosper. (Cabinet Office 2010, p. 11)

On the one hand, this statement argued that the role of nurturing, aspirational parent was not one that 'primarily ... belongs to the state', whilst it also framed the duty of individual parents as one that the government agencies needed to oversee for the good of the state. The emotive and pejorative phrase 'imperil the country's future' in particular framed parents in poverty as group that posed a national threat and therefore must be dealt with by the state. The Report continued by arguing for a raising of the status of what it called 'The Foundation Years', stating:

The Foundation Years brings together all of the current services for children, from the womb until they go to school. The aim is that the Foundation Years will become, for the first time, an equal part of a new tripartite education system: the Foundation Years leading to the school years, leading in turn to further, higher and continuing education. (Cabinet Office 2010, p. 11)

Thus, by framing the Foundation Years as part of a tripartite 'education' system, the Report positioned the intervention of the state in the education of the youngest in society as beginning when the child was in utero. In an inversion of the 19th and 20th century worries about working class mothers being too keen to relinquish their parental duties to the state should early years provision be made to available for under-fives, a key concern of the Report (which was echoed in subsequent government publications on the roll-out of targeted early education provision for two-year-olds) was on the reluctance of families living in poverty to take up the provision. These discourses, underpinning this targeting of families living in poverty and in receipt of certain social security benefits, focused on them being 'hard to reach' and in some cases 'troubled'. The Report stated that respondents to the Review:

believed that services must do much more to effectively engage parents who have traditionally been harder to reach. (Cabinet Office 2010, p. 88)

The Report was underpinned by Field's personal, somewhat rose-tinted and gendered view of parenting in the 1950s and his personal view that the 1960s had heralded a decline in the standard of parenting. In a section of the Report entitled 'Rupturing a good parenting tradition', Field argued:

Geoffrey Gorer, the sociologist, noted in the early 1950s that the spread of a tough love style of parenting had been the agent that changed England from a centuries long tradition of brutality into what was remarked upon by visitors to these shores in the late nineteenth and early twentieth centuries as one of the most peaceful European nations. The tough love tradition of parenting did more than turn England into what was until recently a peaceful self governing kingdom ... But that tough love tradition has recently been in retreat. (Cabinet Office 2010, p. 18)

It must be noted that this valorization of standard of late 19th and early 20th century English working-class parenting stands in stark contrast to the highly critical views written during those times, as discussed earlier in this paper.

In contrast to the highly gendered assumptions of early years provision in the historic texts as aimed at and used by mothers, the Report also stated that a 'number of submissions also emphasized that children's services need to be more 'father-friendly" (Cabinet Office 2010, p. 88). However, in Chapter 1 of the Report, entitled A Personal Commentary, Field's arguments tended to reinforce old-fashioned gender roles and to mourn their erosion since the economic changes of the late 20th century. The Report stated that 'de-industrialization destroyed more than the work ethic in many families and communities' (Cabinet Office 2010, p.18). The loss of their role as breadwinners working in 
male-dominated industry, the Report stated, meant that the 'major means by which many males were socialized into wider society was lost' (Cabinet Office 2010, p. 18). Similarly, the Report positioned the gendered, domestic and economically role of women in this industrialized 1950s society as one to which working class women themselves wished to return. It stressed the importance of full-time employment for fathers 'to family formation and stability' (Cabinet Office 2010, p. 25) but argued for part-time flexible employment for mothers, stating:

The circumstances that made them most happy and contented are having a husband or partner in work so that they can combine their work and their family responsibilities in a pattern that gives primacy to their families. (Cabinet Office 2010, pp. 24-25)

The approach to poverty within the Field Report has tended to be repeated and reflected in policy and reports since 2010, and whatever their gender adults in poverty have been viewed in these discourses as inadequate to the role of parent and their children characterized as inherently and chronically vulnerable (Olusoga 2019). This has been underpinned by a 'catching up' discourse, that frames such children as inevitably 'falling behind' their better off peers academically (Gibb et al. 2010) due to 'gaps' caused by a lack of parental engagement in key tasks (Simpson 2013) such as reading stories that deny such children a state of 'school readiness'.

\subsection{The Revised Early Years Foundation Stage Framework and 'School Readiness'}

One of the recommendations from the Field Report was that funding needed to be provided to extend school-based early years provision to two-year-olds from such family backgrounds. From the initial brief of the Field Report, a discourse of 'school readiness' informed this expansion (Lloyd 2015) and was expressed in the revised EYFS framework (Department for Education DfE). In the introduction to the revised framework the second aim of the EYFS read:

The Early Years Foundation Stage (EYFS) sets the standards that all early years providers must meet to ensure that children learn and develop well and are kept healthy and safe. It promotes teaching and learning to ensure children's 'school readiness' and gives children the broad range of knowledge and skills that provide the right foundation for good future progress through school and life. (Department for Education DfE, p. 2)

At the end of the EYFS, a key aim of the summative Foundation Stage profile was to report to 'parents and carers, practitioners and teachers' the child's 'readiness for Year 1' (Department for Education DfE, p. 11). Readiness for Year 1 was framed as being prepared for 'more formal learning' via a process in the reception year of a 'shift towards more activities led by adults' (Department for Education DfE, p. 6). This revised EYFS thus positioned under-fives as pupils in the making; children who must be made ready for the demands of the National Curriculum, particularly in relation to their becoming literate and numerate prior to the start of Year 1 (Moss 2014).

Alongside this school-readiness orientation, another key element of the revised EYFS has been the 'datafication' of the reception child (Robert-Holmes and Bradbury 2016) and the normative gaze of the Early Learning Goals (ELGs) and the expectation that children achieve a Good Level of Development (GLD). Ensuring school readiness has thus become positioned as the prime function of the EYFS. This is most especially felt in the reception year where the task of the teacher is increasingly focused on the reception child's ability to perform the role of the Year 1 child, and on an alignment of reception class practice with the alleged demands of the National Curriculum, Year 1 pedagogy and curriculum. However, further top-down pressure means that the pressure to conform to more formal practices in the reception year and to produce data, finds similar expression in work with younger children. Thus, paradoxically, the pressure to ensure school readiness becomes the driving force that restricts very young children's engagement with the play-based, child-initiated pedagogy. Whilst research suggests such play-based pedagogies best impact on their abilities for self-regulation, cognitive, physical and social development (Whitebread et al. 2012), the need for children under-five to be able to perform the 
role of 'pupil' in formal pedagogies for the over-fives impacts on the institutional spaces and practices in which they find themselves.

\section{Discussion}

Drawing together the strands of argument presented in this historical review of the subject of the care and education of children under five in schools allows some consideration of the changes and continuities in the official arguments presented. At each stage, discourses about social class and gender have informed debates on the nature and role of school-based provision, the needs of the child under five and the nature of parental responsibility.

\subsection{The Nature and Role of School Provision for Under-Fives}

In 1861, 1908 and 1933 discussion of school attendance for under-fives is torn between conflicting positions. One discourse positions the need for school-based provision for under-fives as unnatural, in that ideally the conditions that make it necessary should not exist. Another discourse positions it as necessary (but only for a sub-set of children) and if suitably designed, capable of compensating for a lack of 'natural' maternal nurturing. There is clear official preference for provision that is formal, school-based and under the scrutiny of inspection, rather than home-based or private provision. The materiality and space of schools as institutions for the under-five is a key focus of discussion. School spaces for under-fives must be adapted or built as spaces distinct from the home and the traditional spaces of elementary schooling. They must offer what is lacking in the home, namely safe and expansive indoor and outdoor spaces, play resources, interaction with adults who are a good influence, and scrutiny and measurement under the normative gaze of the school.

The impact of conflicting discourses is also evident in the 21st century. Whilst maternal employment is now largely seen as a positive, particularly as a means of lifting children out of poverty, the demands of parenting fall unevenly, and mothers tend still to be expected to shoulder the majority of the burden of work involved in the expected partnership between parents and school. Most children, of all social classes, now attend school at age four, in reception classes from the start of the academic year. The situation for younger children, however, is variable due to the fragmented nature of private and public nursery provision and the restricted nature of maternity and paternity pay. The failure of the New Labour government to develop and maintain universal services, the mixed economy of private and state provision and the partial nature of state funding for two, three and four-year-olds in nurseries all mean that in practice provision for under-fives is often divided along lines of social class. The EYFS espouses a discourse of play that requires provision of an enabling environment, space and resources to support indoor and outdoor activity and a holistic approach to learning. However, the focus on data, on development of early literacy and numeracy and on preparation for more formal learning in Year 1 pulls practice in the opposite direction.

\subsection{Changing Conceptualizations of the Young Child}

It is curiously hard to maintain a focus on the actual child in the historical discussion of school provision for under-fives. Where the child is discussed, the argument is often framed in relation to judgements made of the child's parents or about the institutions of home, care or education in which the child is contained. However, it is possible to discern how discourses of social class shape the reasoning about the child and the types of outcomes to be aimed at in schooling the child. The discussions in the 19th and 20th century texts examined all stress the difference between under-fives and older children and emphasize a need to develop provision that is distinctive and age-appropriate. In 1861 the working-class child is framed as a potential street-child and the focus and main purposes of nursery provision are to keep the child contained and to train the child in obedience. In 1908 the focus is on the child living in poverty, a child in physical and moral danger from home and from inadequate maternal care. Here provision must focus on the child's moral training, medical supervision, and organization into classes to facilitate transition into the elementary school. In 1933 the child is understood through 
the lens of psychology and through the now well-established measurement practices of school-based medical supervision. The child under five in nursery provision is not the norm; the natural place is in the home, with the mother, supported by access to medical supervision. For this subset of children, nursery provision conceptualizes the child as being comprised of physical, social and moral aspects that can be measured and impacted upon via the coordinated effort of professionals.

In the 21st century school is increasingly framed as the right place for the child under five. The EYFS has expanded school-based nursery provision, dismantled the practice of multiple intakes of rising fives in the reception year. The child under five is thus a school-child, a person to be cared for and educated simultaneously. Within the under-five label, however, there are now additional subsets. There is the reception year child, who is increasingly conceptualized as a latent Year 1 child, who can and should be treated as such in preparation for being one. The curriculum, and in particular the requirements of the next stage of the curriculum, becomes the scale against which the child is continually measured and judged. There is the two-year-old, from a disadvantaged background, who needs support to catch up. The two-year-old's attendance at school positions education as an intervention capable of offsetting the effects of structural poverty.

\subsection{Changing Conceptualizations of Parental Responsibility}

Changing conceptualizations of parental responsibility can be detected across the historic documents discussed above, particularly in the language used to target and describe and problematize parenting in poverty and the role of the mother. However, two threads of continuity can be found in this shifting discourse. Firstly, working-class parents in poverty are talked about and not to. The perspectives presented in reports are those of professionals working in education and related fields and the officials on boards and committees. Working-class parents living in poverty are considered responsible for and productive of their marginalized social and economic status. Furthermore, the right of the state to develop state apparatus to intervene in their parenting decisions is framed as a social and moral duty for the social, physical and economic health of the nation (Hendrick 1997).

Secondly, these changing conceptualizations of parental responsibility are informed by discourses of gender. In 1861 and 1908 heavy emphasis is placed on the mother. Her place is inside the home and her purpose is to do her maternal duty. The stay at home mother in a good home is an ideal, based on middle class values and privileged economic circumstances. Maternal employment is couched primarily as female selfishness and poverty and poor surroundings as the moral failings of profligacy and lack of effort. The need to compensate for the negative impact of such mothers and homes is countered, however, by a concern that nursery provision may undermine parental responsibility and reward laziness. School provision therefore is to be limited and targeted at a class of family with the understanding that the discipline of school attendance falls as much on the parent as on the child. In the 1933 Report, there is less emphasis on the pejorative discussion of women's employment, maybe reflecting the desperate economic conditions of the economic depression at the time. Instead, nursery school is framed as actively promoting greater parental responsibility, and enhanced by the establishment of classes for mothers, open days for parents and the involvement of parents in supporting the material resourcing of the provision. Although fathers are mentioned and expected to show an interest in their child's schooling, childcare is still framed as the duty of mothers and something for which school needs to prepare girls and not boys.

In the early 21st century, reflecting changes in social norms and family composition, there is a focus in policy on lone parents and parents on social security benefits. Rather than being based on judgements about 'bad housing', it is dependency on welfare benefits that is foregrounded as problematic and potentially productive of a passing on of the 'habit' of poverty between generations. Expanded early years provision is positioned as enabling parents (especially lone mothers) to gain employment, contribute to the economy and in so doing, avoid passing on to their children the 'habit' of being in poverty. In the Field Report, however, we see a discourse that whilst promoting 'father-friendly' practice, also positions men as ideally the main breadwinners, working full time and 
mothers as the main care-givers whose employment should ideally be part-time and flexible. Though the reasoning has shifted, throughout the period, early years provision has been framed as a potential remedy for the social and economic failings of the poor; failings that are often characterized as moral in character. Over recent years a specific social group has been targeted and state provision has been designed to remove the children of that group from the home at an earlier age and for longer periods of time. This state provision has maintained a focus on dividing, sorting and treating children under-five, informed by practices of measurement and the gathering of data. Over time the nature of the data harvested from children has shifted. The early 20th century focus was medically-informed, centred on physical health and development. In the early 21st century this has become a curriculum and accountability-driven focus on school-readiness, as manifested in children's ability to demonstrate their developing literacy and numeracy (Robert-Holmes and Bradbury 2016). Parental responsibility is now tied to discourses of emergent literacy that emphasize the role of speech, story-telling and social interaction and that frame parents in poverty as inevitably creating gaps in their children's experience that must be filled by the state.

Funding: This research received no external funding.

Conflicts of Interest: The author declares no conflict of interest.

\section{References}

Aldrich, Richard. 2006. Lessons from History of Education: The Selected Works of Richard Aldrich. Abingdon: Routledge. Board of Education. 1905a. Code of Regulations for Public Elementary Schools with Schedules. London: HMSO.

Board of Education. 1905b. Reports on Children under Five Years of Age in Public Elementary Schools by Women Inspectors of the Board of Education. London: HMSO.

Board of Education. 1908. Report of the Consultative Committee upon the School Attendance of Children Below the Age of Five. London: HMSO.

Board of Education. 1933. Report of the Consultative Committee on Infant and Nursery Schools. London: HMSO.

Cabinet Office. 2010. The Foundation Years: Preventing Poor Children Becoming Poor Adults. The Report of the Independent Review on Poverty and Life Chances. London: Crown Copyright.

Cremaschi, Sergio. 2014. Utilitarianism and Malthus' Virtue Ethics. London: Routledge.

Department for Children, Schools and Families (DCSF). 2008a. Practice Guidance for the Early Years Foundation Stage. London: DSCF.

Department for Children, Schools and Families (DCSF). 2008b. Statutory Framework for the Early Years Foundation Stage. London: DCSF.

Department for Education (DfE). 2012. Statutory Framework for the Early Years Foundation Stage: Setting the Standards for Learning, Development and Care for Children from Birth to Five. London: Crown Copyright.

Department for Education and Skills (DfES). 2002. Birth to Three Matters. London: DfES.

Education Commission. 1861a. The Newcastle Report. Report of the Commissioners Appointed to Inquire into the State of Popular Education in England. London: HMSO.

Education Commission. 1861b. The Newcastle Report Volume VI. Minutes of Evidence Taken Before the Commissioners. London: HMSO.

Foucault, Michel. 1970. The Order of Things. London: Tavistock.

Foucault, Michel. 1972. The Archaeology of Knowledge. London: Tavistock.

Foucault, Michel. 1977. Discipline and Punish: The Birth of the Prison. London: Allen Lane.

Faulkner, Dorothy, and Elizabeth A. Coates. 2013. Early childhood policy and practice in England: Twenty years of change. International Journal of Early Years Education 21: 244-63. [CrossRef]

Gibb, Jennifer, Helena Jelicic, Ivana La Valle, Sally Gowland, Rachel Kinsella, Patricia Jessiman, and Rachel Ormston. 2010. Rolling out Free Early Education for Disadvantaged Two Year Olds: An Implementation Study for Local Authorities and Providers. Available online: https://assets.publishing.service.gov.uk/government/ uploads/system/uploads/attachment_data/file/181502/DFE-RR131.pdf (accessed on 13 April 2019).

Great Britain. 1918. Education Act 8 \& 9, Geo. 5. C. 39. London: HMSO.

Great Britain. 2006. Childcare Act c. 21. London: HMSO. 
House of Commons Debate. 1870. Elementary Education (re-committed) Bill-[BILL 167]. Hansard vol. 203: 41-95. Heathorn, Stephen. 2000. For Home, Country and Race: Constructing Gender, Class, and Englishness in the Elementary School, 1880-1914. Toronto: University of Toronto Press Inc.

Hendrick, Harry. 1997. Children, Childhood and English Society, 1880-1990. Cambridge: Cambridge University Press. Lloyd, Eva. 2015. Early Childhood Education and Care Policy in England under the Coalition Government. London Review of Education 13: 144-56. [CrossRef]

McDowall Clark, Rory, and Sue Baylis. 2012. "Wasted down there": Policy and practice with the under-threes. Early Years 32: 229-42. [CrossRef]

Moss, Peter. 2014. Early childhood policy in England 1997-2013: Anatomy of a missed opportunity. International Journal of Early Years Education 22: 346-58. [CrossRef]

Office for Standards in Education (Ofsted). 2017. Bold Beginnings: The Reception Curriculum in a Sample of Good and Outstanding Primary Schools. Manchester. Available online: https:/www.gov.uk/government/ publications/reception-curriculum-in-good-and-outstanding-primary-schools-bold-beginnings (accessed on 3 January 2018).

Olusoga, Yinka. 2019. The Contemporary Environment. In Supporting Vulnerable Children in the Early Years. Edited by Pat Beckley. London: Jessica Kingsley Publishers.

Palmer, Amy. 2011. Nursery schools for the few or the many? Childhood, education and the State in mid-twentiethcentury England. Paedagogica Historica 47: 139-54. [CrossRef] [PubMed]

Penn, Helen. 2014. Understanding Early Childhood: Issues and Controversies, 3rd ed. Maidenhead: Open University Press.

Qualifications and Curriculum Authority (QCA). 2000. Curriculum Guidance for the Foundation Stage. London: Department for Education and Employment.

Read, Jane. 2015. Transformation and regulation: A century of continuity in nursery school and welfare policy rhetoric. Journal of Education Policy 30: 39-61. [CrossRef]

Reisigl, Martin, and Ruth Wodak. 2016. The Discourse-Historical Approach (DHA). In Methods of Critical Discourse Studies, 3rd ed. Edited by Ruth Wodak and Michael Meyer. London: Sage, pp. 23-61.

Robert-Holmes, Guy, and Alice Bradbury. 2016. Governance, accountability and the datafication of early years education in England. British Educational Research Journal 42: 600-61. [CrossRef]

Simpson, Donald. 2013. Remediating Child Poverty Via Preschool: Exploring Practitioners' Perspectives in England. International Journal of Early Years Education 21: 85-96. [CrossRef]

Whitebread, David, Marisol Basilio, Martina Kuvalja, and Mohini Verma. 2012. The Importance of Play: A Report on the Value of Children's Play with a Series of Policy Recommendations. Available online: http://www.importanceofplay. eu/IMG/pdf/dr_david_whitebread_-_the_importance_of_play.pdf (accessed on 26 March 2018). 